\title{
KEWAJIBAN NEGARA MELINDUNGI ANAK BANGSA
}

oleh

\author{
YULIANA SURYA GALIH,S.H,.M.H
}

\section{A B S T R A K}

Anak-anak adalah generasi penerus bangsa ini, untuk menghasilkan generasi penerus yang handal, kuat dan tangguh, perlu dipersiapkan sejak dini. Salah satu upaya untuk menciptaan generasi penerus tersebut, maka anak-anak harus tangguh, sehat dan kuat, serta tahan terhadap penyakit. Untuk terciptanya anak-anak yang tahan terhadap penyakit tersebut, maka anak-anak harus diberi imunisasi dengan diberi vaksin.

Tindakan membuat vaksin palsu, dan memberikannya kepada anak-anak, vaksin tersebut tidak mempunyai khasiat atau bahkan bisa membahayakan. Pembuatan vaksin palsu bukan hanya sekedar melanggar aturan hukum yang berkaitan dengan kesehatan yang membawa dampak kerugian kepada konsumen, akan tetapi juga mengenai perlindungan terhadap anak dari dampak vaksin palsu tersebut.

Kewajiban Negaralah yang harus memberikan perlindungan hukum kepada anak-anak, karena Negara sebagai penguasa publik yang mempunyai kewajiban untuk melakukan pengawasan terhadap obat-obat yang beredar di masyarakat.

Kata kunci : anak, vaksin palsu, perlindungan 


\section{Pendahuluan}

Beberapa bulan ke belakang negeri ini kembali dikejutkan oleh pemberitaan vaksin palsu, sementara beberapa minggu lalu media pekarbaran juga menyuguhkan topik mengenai pelecehan seksual terhadap anak dibawah umur, dengan korban mencapai 90 orang lebih. Dua headline news media pekarbaran tersebut membuat orang tua menjadi prihatin, jengkel dan marah, karena yang menjadi korban adalah anak-anak, buah hati dari para orang tua, generasi penerus penerus keluarga dan bangsa Indonesia.

Apresiasi dan penghargaan patut diberikan kepada Kepolisian Negara Republik Indonesia, berkat kerja keras aparat penegak hukum ini, anak-anak bangsa itu bisa diselamatkan.

Kasus vaksin palsu yang berhasil diungkap, bukan hanya sekedar pengungkapan dari kasus dugaan tindak pidana, akan tetapi masalahnya adalah menyelamatkan anak bangsa. Vaksin yang bertujuan untuk memberikan kekebalan terhadap suatu penyakit, apabila vaksin tersebut tidak mempunyai manfaat, maka tidak akan ada kekebelan terhadap tubuh pengguna vaksin tersebut, sehingga penyakit akan muda menyerang, karena tidak ada antibody terhdap penyakit tersebut.

Apabila semua anak-anak yang diberi vaksin palsu, mereka tidak mempunyai kekebalan terhadap penyakit, dengan demikian akan rentan terhadap penyakit, lalu pertanyaannya apakah negeri ini mau generasi penerusnya penyakitan, apakah negeri ini akan dipimpin oleh negerasi yang sakit. Kita tidak pernah tahu dari anak-anak yang menerima vaksin palsu itu akan menjadi para pemimpin negeri ini kelak. 
Praktek pembuatan vaksin palsu tersebut menurut media "Praktik pembuatan vaksin palsu itu disebut-sebut telah berlangsung selama 13 tahun. Orang tua yang pernah mengimunisasi anaknya dalam rentang 13 tahun belakangan ini tentu risau, jangan-jangan anaknya termasuk yang mendapatkan vaksin palsu." (https://m.tempo.co/read/news/.../begini-awalterungkapnya-keberadaan-vaksin-palsu)

Apabila vaksin palsu tersebut telah diproduksi 13 tahun yang lalu, berarti vaksin palsu tersebut sudah beredar hampir di seluruh Indonesia dengan demikian berapa juta anak Indonesia telah kehilangan kekebalan terhadap penyakit, itu berarti satu generasi anak Indonesia tidak kebal terhadap penyakit.

Berdasarkan tabel imunisasi yang diberikan kepada anak, rekomendasasi dari Ikatan Dokter Anak Indonesia (IDAI), yaitu dari usia 0 sampai 18 tahun. (www.idai.or.id uploads/2014)

Dari rentang usia tersebut, imunisasi banyak diberikan kepada anak yang usianya dibawah 10 tahun, jenis vaksin yang diberikan berdasarkan rekomendasi dari IDAI tersebut meliputi :

- Hepatitis B

- Polio

- BCG

- DTP

- Hib

- PCV

- Rotavirus

- Influenza

- Campak

- MMR 
- Tifoid

- Hepatitis A

- Varisela

- HPV

Dalam kasus vaksin palsu tersebut, masalahnya bukan hanya sekedar, tindak pidana pemalsuan terhadap obat, akan tetapi adalah bagaimana anak sebagai penerus generasi bangsa ini mendapatkan perlindungan, perlakukan yang layak, bukan hanya dari segi pendidikan, namun juga dari bahayabahaya penyakit yang mungkin dapat menyerang kepada anak-anak. Bangsa ini harus menyiapkan generasi muda yang sehat dan tangguh.

Bagaimana anak-anak bangsa ini akan menjadi anak-anak yang sehat dan tangguh, apabila vaksin yang diberikan kepada mereka tidak bekerja dan tidak memberikan daya tahan tubuh terhadap penyakit.

Apabila benar vaksin palsu tersebut sudah beredar 13 tahun yang silam, lalu kemanakah peran dari Kementerian Kesehatan, Badan Pengawasan Obat dan Makanan, selaku otoritas yang mengawasi semua produk obat dan makanan, kemanakah peran dari dua lembaga yang bertanggungjawab di bidang kesehatan tersebut.

Kemanakah Negara selama ini. Negera selaku penguasa publik wajib melindungi segenap bangsa Indonesia, terlebih lagi melindungi anak-anak sebagai generasi penerus bangsa. Undang-undang Dasar 1945 telah memberikan jaminan perlindungan terhadap anak-anak sebagaimana ditentukan didalam 28B ayat (2) UUD 1945, selain itu didalam Deklarasi Universal Hak Asasi Manusia pada 10 Desember 1948 Selanjutnya upaya perlindungan anak juga direspon dalam Majelis Umum PBB yang kembali mengeluarkan pernyataan Deklarasi Hak Anak pada 20 November 1959. 


\section{Pembahasan}

\subsection{Terbentuknya Negara dan Tujuan Negera}

Sudah menjadi kodrat alam, bahwa manusia sejak dahulu kala selalu hidup bersama-sama dalam suatu kelompok (zoon politicon). Dalam kelompok manusia itulah mereka berjuang bersama-sama mempertahankan hidupnya mencari makan, melawan bahaya dan bencana serta melanjutkan keturunannya. Mereka berinteraksi, mengadakan hubungan sosial. Untuk mempertahankan hak mereka untuk dapat hidup di tempat tinggal tertentu yang mereka anggap baik untuk sumber penghidupan, diperlukan seseorang atau sekelompok kecil orangorang yang ditugaskan mengatur dan memimpin kelompoknya. Kepada pemimpin kelompok inilah diberikan kekuasaan-kekuasaan tertentu dan kelompok manusia tadi diharuskan menaati peraturan-peraturan perintah pemimpinnya.(C.S.T. Kansil, 2001:133)

Negara merupakan kehendak dari manusia dalam pergaulan antara seorang dengan orang lainnya dalam rangka memenuhi segala kebutuhan hidupnya. Semakin luas pergaulan manusia maka semakin banyak kebutuhan yang harus dipenuhi, maka semakin bertambah besar pula kebutuhan kepada organisasi negara yang harus melindungi dan memelihara hidupnya.

Menurut Plato, negara adalah suatu tubuh yang senantiasa maju, berevolusi dan terdiri dari orang-orang (individu-individu) yang timbul atau ada karena masing-masing dari orang itu secara sendiri-sendiri tidak mampu memenuhi kebutuhan dan keinginannya yang beraneka ragam, yang menyebab-kan mereka harus bekerja sama untuk memenuhi 
kepentingan mereka bersama. Kesatuan inilah yang kemudian disebut masyarakat atau Negara.(Soehino, 1980: 17)

Manusia sebagai mahluk social, tidak bisa hidup sendiri-sendiri tanpa bantuan orang lain, dan mereka akan senantiasa untuk saling berhubungan dengan orang lain untuk memenuhi kebutuhan hidupnya, hal ini sesuai degan doktrin yang diajarkan oleh Aristoteles, dengan istilah zoon politicon atau manusia sebagai mahluk sosial.

Menurut Thomas Hobbes bahwa negara adalah suatu tubuh yang dibuat oleh orang banyak beramai-ramai, yang masing-masing berjanji akan memakainya menjadi alat untuk keamanan dan pelindungan mereka. Berdasarkan pengertian yang disampaikan oleh sarjana ini adalah bahwa suatu negara terbentuk oleh sekumpulan manusia yang menyatukan dirinya dan kemudian mengadakan perjanjian antar sesama mereka untuk menjadikan negara yang mereka bentuk sendiri sebagai alat untuk keamanan dan perlindungan bagi mereka (Teori Perjanjian Masyarakat atau teori kontrak sosial). Dari sini juga dapat diketahui bahwa negara dibentuk dalam rangka memberikan rasa aman dan perlindungan bagi masing-masing mereka, yang berarti juga bahwa manusia menyadari mereka dapat menjadi serigala bagi sesamanya (homo homini lupus) dalam pencapaian kepentingan masing-masing mereka, yang kemudian dalam skala yang besar dapat menyebabkan terjadinya perlawanan atau perang (bellum omnium contra omnes).

Menurut George Jellinek yang juga disebut sebagai Bapak Negara memberikan pengertian tentang Negara yang merupakan organisasi 
kekuasaan dari kelompok manusia yang telah berdiam di suatu wilayah tertentu.

Negara sebagai suatu organisasi kekuasaan manusia/ masyarakat dan merupakan sarana untuk tercapainya tujuan bersama. Beberapa pandangan tentang tujuan Negara :

Menurut Plato Negara bertujuan untuk memajukan kesusilaan manusia sebagai individu dan sebagai makhluk sosial. Machiaveli dan Shang Yng mengatakan bahwa Negara bertujan untuk memperluas kekuasaan semata-mata, tujuan Negara didirikan adalah untuk menjadikan Negara itu besar dan jaya. Untuk mencapai kejayaan Negara, maka rakyat harus berkorban, kepentingan orang perorangan harus diletakkan di bawah kepentingan bengsa dan Negara, Negara Diktator. Kalau ingin Negara kuat dan jaya, maka rakyat harus lunakkan dan sebaliknya jika orang menghendaki rakyat menjadi kuat dan kaya, maka Negara itu menjadi lemah. (repository.unpad.ac.id/1571/1/hukum_tata_negara.pdf)

Ajaran Teokrasi (Kedaulatan Tuhan) Thomas Aquino, Agustinus, Tujuan negara adalah untuk mencapai penghidupan dan kehidupan aman dan tentram, dibawah pimpinan Tuhan. Pimpinan negara menjalankan kekuasaannya berdasar-kan Kehendak Tuhan. (repository.unpad.ac.id/1571/1/hukum_tata_negara.pdf)

Ajaran Negara Hukum (Krabbe), Negara bertujuan menyelenggarakan ketertiban hukum. Segala kekuasaan dan alat-alat Negara dalam menjalankan tugasnya harus berdasarkan hukum, semua orang tanpa kecuakli harus tunduk dan taat pada hukum, hanya hukumlah 
yang berkuasa dalam Negara (Rule of Law). Negara Kesejahteraan (Welfare State $=$ Soscial Service State), Tujuan Negara adalah mewujudkan kesejahteraan umum. Negara sebagai alat untuk tercapinya tujuan bersama yaitu kemakmuran, kebahagian dan keadilan sosial bagi seluruh rakyat. (repository.unpad.ac.id/1571/1/hukum_tata_negara.pdf)

Tujuan Negara Republik Indonesia tercantum baik didalam pembukaan Undang-Undang Dasar Negera Republik Indonesia tahun 1945 maupun didalam Batang Tubuh atau Isi dari UUD 1945. Tujuan dari Negara Republik Indonesia antara lain adalah melindungi segenap bangsa Indonesia dan seluruh tumpah darah Indonesia dan untuk memajukan kesejahteraan umum, mencerdaskan kehidupan bangsa.

Pasal 28 B Undag-undang Dasar Republik Indonesia tahun 1945 telah jelas memberikan perlindungan terhadap anak, dan salah satu dari penjabaran pasal 28B UUD 1945 tersebut, dikeluarkanlah berbagai macam peraturan perundang-undangan yang berkaitan dengan perlindungan anak diantaranya adalah Undang-undang No. 4 tahun 1979 tentang Kesejahteraan Anak, Undang-undang No. 39 tahun 1999 tentang Hak Asasi Manusia, Undang-undang No. 23 tahun 2002 tentang Perlindungan Anak, Undang-undang No. 11 tahun 2012 tentang Sistem Peradilan Anak.

Dari berbagai macam peraturan undang-undang tersebut merupakan bentuk perlindungan yang diberikan oleh Negara kepada anak-anak, secara formal, yang harus dijalankan oleh pemerintah.

Kasus vaksin palsu bukan hanya sekedar masalah tindak pidana saja, melainkan juga masalah perlindungan terhadap anak-anak, dimana 
Negara harus hadir untuk melindungi mereka, bukan sekedar memproses hukum dari para pelaku pemalsuan tersebut dengan hanya menjerat dengan pasal pemalsuan saja.

\subsection{Tindak Pidana Pemalsuan Obat}

Tindak pidana pemalsuan telah diatur didalam KUHP, akan tetapi pemalsuan yang dimaksud didalam KUHP tersebut, pemalsuan yang berkaitan antara lain dengan tanda tangan palsu, stempel palsu, memberikan keterangan palsu, pemalsuan surat dan menggunakan surat palsu.

Tindak Pidana pemalsuan adalah kejahatan yang di dalamnya mengandung unsur keadaan ketidakbenaran atau palsu atas sesuatu (obyek), yang sesuatunya itu tampak dari luar seolah-olah benar adanya padahal sesungguhnya bertentangan dengan yang sebenarnya (Adami Chazawi, $2001: 2)$.

Pemalsuan obat masuk dalam kategori kejahatan perbuatan curang (bedrog) atau lebih dikenal dengan kejahatan penipuan. Maksud dari adanya pembedaan ini adalah apabila dalam pemalsuan yang dilindungi adalah kepercayaan akan kebenaran dari keenam obyek pemalsuan, sedangkan dalam penipuan yang diberikan adalah perlindungan hukum bagi masyarakat dari perbuatan yang bersifat menipu, membohongi atau memberdayakan orang. Orang akan merasa tertipu, terpedaya dan karenanya menderita kerugian bilamana mendapatkan benda yang dikiranya benar atau asli padahal sesungguhnya palsu (Adami Chazawi, $2001: 4)$. 
Pengertian Obat Palsu menurut Peraturan Menteri Kesehatan Nomor 1010/Menkes/Per/XI/2008 tentang Registrasi Obat, Obat palsu adalah Obat yang diproduksi oleh yang tidak berhak berdasarkan peraturan perundang-undangan yang berlaku atau produksi obat dengan penandaan yang meniru identitas obat lain yang telah memiliki izin edar.

Menurut Organisasi kesehatan dunia (WHO) mengatakan According to the WHO, a counterfeit drug is one which is deliberately and fraudulently mislabeled with respect to identity, composition, and/or source.' This definition of counterfeit includes not only completely fake drugs but also those that have been tampered with, adulterated, diluted, repackaged, or relabeled so as to misrepresent the dosage, origin, or expiration date, as well as those substandard drugs that are cheaply produced in order to make unlawful profits. (Indian Journal of Pharmacology, 2007:206)

Dalam Pasal 386 Ayat (1) KUHP mengatur mengenai pemalsuan obat yaitu Barangsiapa menjual, menawarkan atau menyerahkan barang makanan, minuman atau obat-obatan yang diketahui bahwa itu dipalsu, dan menyembunyikan hal itu, diancam dengan pidana penjara paling lama empat tahun.

Tindak pidana di bidang kesehatan adalah semua perbuatan di bidang pelayanan kesehatan atau yang berhubungan atau yang menyangkut pelayanan kesehatan yang dilarang oleh undang-undang disertai ancaman pidana tertentu terhadap siapapun yang melanggar larangan tersebut. Dengan demikian, objek tindak pidana di bidang kesehatan adalah pelayanan kesehatan atau segala hal yang menyangkut 
atau berhubungan dengan pelayanan kesehatan (Adami Chazawi, 2007 : 147).

Pemalsuan terhadap obat-obatan atau yang berkaitan dengan farmasi terdapat didalam Undang-undang No. 36 tahun 2009. Didalam undang-undang tersebut telah diatur mengenai perbuatan apa saja yang dilarang yang berkaitan dengan memproduksi atau mengedarkan sediaan farmasi dan/ atau alat kesehatan yang tidak memenuhi standar.

Bahwa pelaku kejahatan pemalsuan vaksin dijerat dengan menggunakan pasal 196,197 dan 198 Undang-undang No. 36 tahun 2009 tentang Kesehatan, selain itu pula dijerat dengan pasal 62 jo pasal 8 Undang-undang No. 8 tahun 1999 tentang Perlindungan Konsumen.

Bahwa ketentuan-ketentuan pidana yang terdapat didalam pasal 196 menyatakan :

Setiap orang yang dengan sengaja memproduksi atau mengedarkan sediaan farmasi dan/atau alat kesehatan yang tidak memenuhi standar dan/atau persyaratan keamanan, khasiat atau kemanfaatan, dan mutu sebagaimana dimaksud dalam Pasal 98 ayat (2) dan ayat (3) dipidana dengan pidana penjara paling lama 10 (sepuluh) tahun dan denda paling banyak Rp1.000.000.000,00 (satu miliar rupiah).

Ketentuan pasal 197 Undang-undang No. 36 tahun 2009, menyatakan :

Setiap orang yang dengan sengaja memproduksi atau mengedarkan sediaan farmasi dan/atau alat kesehatan yang tidak memiliki izin edar sebagaimana dimaksud dalam Pasal 106 ayat (1) dipidana dengan pidana penjara paling lama 15 (lima belas) tahun dan denda paling banyak Rp1.500.000.000,00 (satu miliar lima ratus juta rupiah).

Kemudian ketentuan pasal 62 Undang-undang No. 8 tahun 1999 tentang Perlindungan Konsumen merupakan ketentuan pidana terhadap larangan-larangan yang telah ditentukan didalam pasal 8 Undang-undang No. 8 tahun 1999. 
Undang-undang No. 8 tahun 1999 ditujukan untuk melindungi konsumen dari perbuatan-perbuatan curang dari para pelaku usaha. Dengan adanya undang-undang ini diharapkan konsumen mendapatkan perlindungan hukum dari perbuatan curang, yang menimbulkan kerugian bagi konsumen.

Masyarakat yang telah membeli vaksin palsu bagi anak-anaknya jelas mengalami kerugian bukan hanya sekedar materi akan tetapi juga timbulnya kekhawatiran yang timbul sebagai akibat vaksin palsu tersebut. Sebab vaksin yang tadinya diharapkan akan memberikan kekebalan tubuh bagi anak, ternyata tidak mempunyai khasiat sama sekali, sedangkan konsumen telah membeli vaksin tersebut dengan harga yang relative mahal.

Setelah temuan yang dilakukan oleh para penegak hukum dan ramai menjadi perhatian publik di Indonesia, ada fakta bahwa kepentingan masyarakat tak diindahkan. Masyarakat khususnya para orang tua dari bayi dan anak yang diduga telah diberikan vaksinasi dengan vaksin palsu tersebut, tak menemui jalan solutif terkait kasus yang menimpa anak-anak mereka. Walaupun pemerintah telah membentuk posko-posko untuk melakukan vaksinasi ulang. Tetapi itu tidak cukup sampai disitu, karena kemungkinan vaksin palsu sudah beredar jauh, dan mungkin saja tidak semua masyarakat yang mempunyai anak atau bayi tidak melakukan vaksinasi ulang.

Kementerian Kesehatan dalam hal ini melalui Badan Pengawasan Obat dan Makanan (BPOM) adalah adalah badan yang 
bertanggungjawab atas segala bentuk peredaran obat-obatan dan makanan yang ada dimasyarakat.

Dalam kasus vaksin palsu, kemanakah lembaga ini, padahal seharusnya BPOM harus melakukan pengawasan terhadap vaksin-vaksin yang akan beredar, apalagi vaksin palsu tersebut sudah beredar bertahun-tahun, berarti dalam hal ini telah terjadi kelalaian dari lembaga berwenang yang seharusnya melakukan pengawasan. Dan kasus ini terbongkar bukan atas kerja dari BPOM melainkan atas kerja keras aparat kepolisian.

Terbongkarnya kasus vaksin palsu bukan hanya sebatas perbuatan curang dari produsen vaksin yang telah melanggar ketentuan Undangundang No. 36 tahun 2009, akan tetapi juga bagaimana konsumen yang telah dirugikan oleh beredarnya vaksin palsu mendapatkan perlindungan hukum.

Perlindungan Konsumen ditujuan agar masyarakat muendapatkan jaminan hukum dari suatu produk yang dikeluarkan oleh pelaku usaha.

Dalam perlindungan konsumen, masih terjadi ketidakseimbangan antara konsumen dengan pelaku usaha, ketidakseimbangan tersebut dijembatani melalui Hukum Perlindungan Konsumen.

Az. Nasution berpendapat bahwa hukum perlindungan konsumen adalah bagian dari hukum konsumen yang memuat asas-asas atau kaidah-kaidah yang bersifat mengatur dan mengandung sifat yang melindungi kepentingan konsumen, sedangkan hukum konsumen adalah hukum yang mengatur hubungan dan masalah antara berbagai pihak satu 
sama lain berkaitan dengan barang atau jasa konsumen di dalam pergaulan hidup. (Shidarta, $2006: 11$ )

Di Amerika Serikat pengertian konsumen consumer (dalam BAhasa Inggris) berarti pemakai, namun dapat juga diartikan lebih luas lagi sebagai korban pemakaian produk yang cacat, baik korban tersebut pembeli, bukan pembeli tetapi pemakai, bahkan korban yang bukan pemakai, karena perlindungan hukum dapat dinikmati pula oleh korban yang bukan pemakai. (Celina Tri Siwi Kristiyanti, 2009 :23)

Perlindungan Konsumen berdasarkan Pasal 1 angka 1 UndangUndang Nomor 8 Tahun 1999 adalah segala upaya yang menjamin adanya kepastian hukum untuk memberi perlindungan kepada konsumen. Sedangkan pengertian konsumen Pasal 1 angka 2 Undang-undang No. 8 tahun 1999 adalah setiap orang pemakai barang dan/ atau jasa yang tersedia dalam masyarakat, baik bagi kepentingan diri sendiri, keluarga, orang lain maupun makhluk hidup lain dan tidak untuk diperdagangkan

Barang berdasarkan ketentuan Pasal 1 angka 4 Undang-undang No. 8 tahun 1999 adalah setiap benda baik berwujud maupun tidak berwujud, baik bergerak maupun tidak bergerak, dapat dihabiskan maupun tidak dapat dihabiskan, yang dapat untuk diperdagangkan, dipakai, dipergunakan, atau dimanfaatkan oleh konsumen

Kedua undang-undang tersebut telah menentukan sanksi pidana yang cukup berat bagi pelaku yang melakukan tindak pidana pemalsuan terhadap suatu obat atau vaksin. Obat atau vaksin palsu tidak memeliki khasiat sebagaimana yang diharapkan untuk penyembuhan terhadap 
suatu penyakit atau memiliki kekebalan terhadap suatu penyakit, akan tetapi kemungkinan akan menimbulkan dampak buruk bagi kesehatan.

\subsection{Perlindungan Anak}

Anak sebagai generasi penerus bangsa ini, diharapkan menjadi generasi penerus yang tangguh dan tahan terhadap penyakit-penyakit yang berbahaya. Sehingga sejak dini harus diberi kekebalan dan daya tahan terhadap penyakit dengan cara diberi vaksin.

Masalah perlindungan anak, merupakan issu yang sudah ada sejak akhir Perang Dunia I, sebagai bentuk upaya masyarakat dunia untuk melindungi anak adalah dengan lahirnya Piagam Deklarasi Universal Hak Asasi Manusia pada 10 Desember 1948. Pasal 25 ayat (2) Deklarasi Universal Hak Asasi Manusia tersebut menyebutkan bahwa Ibu dan anakanak berhak mendapatkan perhatian dan bantuan khusus. Semua anak, baik yang dilahirkan di dalam maupun di luar perkawinan, harus menikmati perlindungan sosial yang sama.

Upaya perlindungan anak akhirnya membuahkan hasil nyata dengan dideklarasikan Konvensi Hak Anak (Convention on the Rights of The Child) secara bulat oleh Majelis Umum PBB pada tanggal 20 November 1989 (Resolusi PBB No.44/25 tanggal 5 Desember 1989). Sejak saat itu, maka anak-anak seluruh dunia memperoleh perhatian khusus dalam standar Internasional.

Indonesia sebagai anggota PBB, meratifikasi Konvensi Hak Anak melalui Keputusan Presiden No. 36 Tahun 1990 Tentang Konvensi HakHak Anak (Convention on the Rights of the Child) yang menandakan 
bahwa Indonesia secara nasional memiliki perhatian khusus terhadap hak-hak anak. Berkaitan dengan penjabaran hak-hak anak dalam Konvensi Hak Anak, telah dijabarkan sebelumnya yang pada prinsipnya memuat empat kategori hak anak, yakni hak terhadap kelangsungan hidup (survival rights), hak terhadap perlindungan (protection rights), hak untuk tumbuh kembang (development rights), dan hak untuk berpartisipasi (participation rights). (M. Nasir Djamil, 2013:26-27)

Dua belas tahun setelah keluar Keputusan Presiden No. 36 Tahun 1990, baru pada tahun 2002 secara hukum positif Indonesia mempunyai Undang-undang yang secara khusus mengatur tentang perlindungan terhadap anak, yaitu dengan diundangkannya Undang-undang No. 23 tahun 2002 tentang Perlindungan anak.

Tujuan perlindungan anak, sebagaimana tercantum didalam pasal 3 Undang-undang No. 23 tahun 2002 yaitu untuk menjamin terpenuhinya hak-hak anak agar dapat hidup, tumbuh, berkembang, dan berpartisipasi secara optimal sesuai dengan harkat dan martabat kemanusiaan, serta mendapat perlindungan dari kekerasan dan diskriminasi, demi terwujudnya anak Indonesia yang berkualitas, berakhlak mulia, dan sejahtera.

Kemudian setiap anak berhak untuk berhak memperoleh pelayanan kesehatan dan jaminan sosial sesuai dengan kebutuhan fisik, mental, spiritual, dan sosial, hal ini sebagaimana disebutkan didalam pasal 8 Undang-undang No 23 tahun 2002.

Undang-undang No. 4 tahun 1979 tentang Kesejahteraan Anak dan Undang-undang No 23 tahun 2002 tentang Perlindungan Anak merupakan 
perwujudan hak asasi manusia dan perlindungan anak untuk mewujudkan generasi penerus bangsa yang berkualitas. Hak-hak anak tersebut tercantum didalam ketentuan Pasal 2 sampai dengan Pasal 8 Undangundang No. 4 tahun 1979 Kesejahteraan Anak diantaranya :

a. anak berhak atas kesejahteraan, perawatan, asuhan dan bimbingan berdasarkan kasih sayang baik dalam lingkungan keluarganya maupun didalam asuhan khusus untuk tumbuh dan berkembang secara wajar;

b. anak berhak atas pelayanan untuk mengembangkan kemampuan dan kehidupan sosialnya dengan baik dan berguna;

c. anak berhak ats pemeliharaan dan perlindungan, baik semasa dalam kandungan maupun sesudah dilahirkan;

d. anak berhak ats perlindungan terhadap lingkungan hidup yang dapat membahayakan atau menghambat pertumbuhan dan perkembangan secara wajar

Fakta menunjukan masih banyak anak-anak yang belum memperoleh hak-haknya sesuai dengan yang diamanatkan oleh UUD 1945 maupun Undang-undang perlindungan anak. Hal dapat dilihat dari masih banyak anak-anak yang seharusnya memperoleh pendidikan namun karena keadaan ekonomi yang sulit, sehingga anak tersebut harus bekerja. Bahkan tidak sedikit pula anak-anak yang turun ke jalan, entah itu menjadi pengamen, pengemis atau gelandangan.

Sementara itu penelantaran hak-hak anak atau pengabaian terhadap hak-hak anak dapat dilihat pada tempat-tempat umum yaitu pengemis jalanan yang menggendong bayi dengan kasih sayang demi sesuap nasi, pembuangan bayi, gizi buruk sampai penularan HIV/ Aids. Melihat pada situasi tersebut, maka negara sebagai penjamin harus mampu memberikan perlindungan kepada mereka. 
Anak sebagai orang yang secara fisik dan mental belum mempunyai kemampuan apa-apa, menjadikan anak rentan untuk diperlakukan secara tidak wajar, oleh sebab itulah agar anak tumbuh menjadi anak yang kuat dan sehat harus diberikan imunitas yang cukup baik. Pemberian vaksin terhadap anak adalah salah satu upaya untuk memberikan kekebalan terhadap anak tersebut.

Kasus vaksin palsu harus dipandang sebagai pelanggaran terhadap perlindungan terhadap anak, karena korbannya anak-anak.

Apabila melihat ketentuan Undang-undang No. 23 tahun 2002, yang telah diubah dengan Undang-undang No. 35 tahun 2014 dan terakhir dengan Perpu No. 1 tahun 2016, tidak ada satu pasal yang mengatur mengenai anak-anak yang menjadi korban dari suatu perbuatan curang akibat dari suatu produk dan sanksi pidana bagi pelaku yang melakukan pebuatan curang dalam suatu produk. Padahal anakpun telah menjadi sasaran dari produk-produk ilegal. Faktanya banyak produk seperti makanan anak-anak yang membahayakan bagi anak-anak.

Pembuat vaksin palsu sebenarnya sadar betul bahwa vaksin dibuat untuk memberikan imunitas kepada anak-anak, dengan demikian para pelaku pembuat vaksin palsu sadar bahwa anak-anak akan menjadi korban dari tindakan tersebut.

Bahwa walaupun memang benar pembuatan vaksin palsu itu dan obat-obatan yang dibuat tidak sesuai dengan khasiatnya merupakan pelanggaran terhadap Undang-undang No. 36 tahun 2009 dan konsumen telah dirugikan akibat vaksin palsu juga merupakan perbuatan yang melanggar ketentuan Undang-undang No. 8 tahun 1999 tentang 
Perlindungan Konsumen, namun sebenarnya apabila dilihat, yang menjadi target korban dari pembuatan vaksin palsu adalah anak-anak, sedangkan anak-anak wajib dilindungi dari segala bentuk tindakan kekerasan baik fisik maupun fhisikis yang merugikan bagi anak itu sendiri, maka disini telah berlaku Undang-undang Perlindungan Anak. 


\section{KESIMPULAN}

Anak merupakan generasi penerus bangsa yang harus mendapatkan perhatian semua pihak, baik keluarga, masyarakat maupun pemerintah. Untuk mempersiapkan generasi penerus tersebut, anak harus sehat dan kuat, tidak gampang sakit dan tahan terhadap segala macam penyakit yang mungkin akan menyerangnya. Untuk tahan terhadap penyakit itulah, maka anak-anak harus diberi imunisasi dengan memberikan vaksin.

Kasus vaksin palsu, tidak memberikan efek dan khasiat apapun terhadap anak, atau bahkan bisa bisa berbahaya bagi anak itu sendiri.

Negara sebagai penguasa publik mempunyai kewajiban untuk melindungi anak-anak Indonesia dari segala bentuk tindakan yang akan merugikan anak itu sendiri. Kasus vaksin palsu bukan hanya sekedar masalah tindak pidana pemalsuan obat dan masalah kerugian bagi konsumen yang telah diatur baik didalam Undang-undang No. 36 tahun 2009 tentang Kesehatan maupun Undang-undang No. 8 tahun 1999 tentang Perlindungan Konsumen, akan tetapi masalah perlindungan anak itu harus diberikan oleh Pemerintah, jangan sampai anak-anak harus menjadi korban dari ketidakberdayaan. 


\section{DAFTAR PUSTAKA}

Chazawi. Adami, Kejahatan Terhadap Pemalsuan: PT Raja Grafindo Persada. . Jakarta 2001.

Pelajaran Hukum Pidana I, PT Raja Grafindo Persada, Jakarta, 2002.

Malpraktik Kedokteran Tujuan Norma dan Doktrin Hukum, Banyumedia, Malang, 2007.

Djamil, M. Nasir, Anak Bukan Untuk Dihukum,: Sinar Grafika, Jakarta, 2013.

Halim, Abdul Barkatulah, Hukum Perlindungan Konsumen (Kajian Teoretis dan Perkembangan Pemikiran), Nusa Media, Bandung, 2008.

Kansil, CST, IImu Negara Umum dan Indonesia, PT. Pradnya Paramita, Jakarta, 2001.

Shidarta, Hukum Perlindungan Konsumen Indonesia edisi Revisi 2006, Gramedia Widiasarana Indonesia, Jakarta, 2006.

Sjahputra, Iman, Perlindungan Konsumen dalam Transaksi Elektronik, Alumni, Bandung, 2010.

Soehino, Ilmu Negara, Liberty, Yogyakarta, 1980.

Tri Siwi Kristiyanti, Celina, Hukum Perlindungan Konsumen, Sinar Grafika, Jakarta, 2009.

\section{e.JURNAL}

Azhar Khan and Naushad Ghilzai. 2007. Counterfeit and substandard quality of drugs: The need for an effective and stringent regulatory control in India and other developing countries. Indian Journal of Pharmacology. Vol. 39, No. 4 


\section{PERATURAN PERUNDANG-UNDANGAN}

Kitab Undang-Undang Hukum Pidana (KUHP)

Undang-undang Dasar Negara Republik Indonesia 1945.

Undang-undang No. 4 tahun 1979 tentang Kesejahteraan Anak.

Undang-undang No. 8 tahun 1999 tentang Perlindungan Konsumen.

Undang-undang No. 23 tahun 2002 tentang Perlindungan Anak.

Undang-undang No. 36 tahun 2009 tentang Kesehatan.

Undang-undang No. 35 tahun 2014 tentang Perubahan Atas Undang-undang No. 23 Tahun 2002 Tentang Perlindungan Anak.

Peraturan Pemerintah Pengganti Undang-undang No. 1 tahun 2016 Perubahan Kedua atas Undang-undang No. 23 Tahun 2002 tentang Perlindungan Anak.

Peraturan Menteri Kesehatan Nomor 1010/Menkes/Per/XI/2008 tentang Registrasi Obat.

\section{SUMBER LAIN}

(https://m.tempo.co/read/news/.../begini-awal-terungkapnya-keberadaan-vaksinpalsu)

(www.idai.or.id uploads/2014)

(repository.unpad.ac.id/1571/1/hukum_tata_negara.pdf) 